\title{
Factors Affecting Job Satisfaction of Public Librarians: A Qualitative Exploration in the Kandy District, Sri Lanka
}

B. M. M. C. B. Hindagolla ${ }^{1}$ and S. Weerasinghe ${ }^{2}$

\begin{abstract}
Employees are one of the main assets in any organization. Public libraries are prominent social entities which provide information and services to local communities to enhance their knowledge and learning. In order to provide quality and commendable services to the public, employees serving in public libraries should be satisfied with their job. Therefore, the assessment of employee satisfaction with their job is essential for organizational development. The main purpose of this study was to examine whether Public Librarians working in the Kandy District of Sri Lanka were satisfied with their job in terms of five facets: job role, work supervision, promotion, salary and co-worker relationships. Further, this study explored problems militating against the Public Librarians' job satisfaction. A convenient sample of 27 librarians from public libraries in the Kandy District of Sri Lanka was selected for the study. Five focus group discussions using a semi structured interview guide were
\end{abstract}

${ }^{1}$ Senior Assistant Librarian, Faculty of Science, University of Peradeniya. Email: menakah@pdn.ac.lk iD https://orcid.org/0000-0002-4358-6035 ${ }^{2}$ Senior Assistant Librarian, Veterinary Medical Library, University of Peradeniya.

Email: sureniw1@yahoo.com iD https://orcid.org/0000-0001-7337-8408 
conducted. Interviews were analyzed using the thematic approach and content analysis. According to the findings, majority of the Public Librarians expressed satisfaction towards their job role and co-worker relationships where as most of them articulated negative opinions with regard to the facets of salary, promotion and work supervision. Based on the results, recommendations were exposed with a view to enhancing the level of job satisfaction among Public Librarians which will in turn contribute to the success of the public library sector in Sri Lanka.

Keywords: Public Libraries, Job Satisfaction, Public Librarians, Central Province, Sri Lanka 


\section{Introduction}

Job satisfaction among employees of an organization is a crucial factor in the provision of commendable services to its user base. 'Job' is not merely an employment; rather it extends further to mean an activity that creates value to and for the community (Igbashal et al., 2016). As it offers value to the person as well as to the society, job satisfaction will enhance the quality and performance of the employee.

Job satisfaction can be expressed as "an individual's total feelings about the job and the attitudes they have towards various aspects or facets of their job, as well as an attitude and perception that could consequently influence the degree of fit between the individual and organization" (Ivancevich \& Matteson, 2002; Spector 1997 as cited in Esakkimuthu \& Vellaichamy, 2015, p. 23). Furthermore, Hulin and Judge (2003) outline that job satisfaction spans multi-dimensional psychological reactions to a person's job and such a response constitutes cognitive (evaluative), affective (emotional) and behavioral elements.

Employee satisfaction with their jobs directly imposes an impact on the successful achievement of organizational goals (Marasinghe \& Wijayaratne, 2018). Besides, 'job satisfaction' is an important notion which directly influences work related behaviors such as productivity and co-worker relationships (Igbashal et al., 2016). Employees with a high level of satisfaction towards their jobs are more inclined to perform their tasks exceeding the normal expectations such as working long hours if required (Iurun, 2014). Olusegun (2013) asserts that such employees generally prefer their jobs, perceive they are treated fairly and consider they have beneficial job aspects such as interesting work, high pay and job security. Employee satisfaction in the work place will open avenues 
for enhancing the effectiveness and efficiency of the organization as well as to gain competitive advantage. On the other hand, dissatisfied employees might continuously seek for new opportunities, instead of engaging in their current duties productively. Employee turnover and dissatisfaction can be detrimental for an organization. An organization would lose well experienced and knowledgeable people through staff turnovers which will have a negative effect on the sustainability of the organization.

Public libraries are one of the prominent social entities which provide information and services to local communities to enhance their knowledge and learning. As the name implies, public library is for the people, by the people and of the people (Kaliya \& Bahskarn, 2010). Public libraries play a significant role in gathering, organizing and exploiting information as well as in providing access to a broad variety of information sources. UNESCO has defined the public library as "the local gateway to knowledge, provides a basic condition for lifelong learning, independent decision making and cultural development of the individual and social group" (IFLA/UNESCO, 1994, para 2). Public libraries are a public property. Thus, it is necessary to sustain well trained, highly motivated and satisfied staff for the effective utilization of the library resources which will pave the way to fulfill the demands of the community.

Several researchers around the globe have focused on examining job satisfaction of library employees. However, there is a dearth of studies, in particular qualitative studies, which have emphasized on the factors affecting the job satisfaction of Public Librarians in the context of Sri Lanka. Therefore, the present study was an empirical attempt to 
assess the job satisfaction of Public Librarians in the Central Province of Sri Lanka. The recommendations made in the light of the findings will aid in enhancing the level of job satisfaction among Public Librarians in Sri Lanka which will in turn help form a motivated and productive work force for the success of the public library sector.

\section{Problem Statement}

There are many instances depicting that some Public Librarians are actually not content with their jobs. Previous studies have shown that Public Librarians in the North Central Province of Sri Lanka exhibited low satisfactory levels with regard to their promotion schemes and that they showed both positive and negative signs towards job satisfaction (Wanasinghe, 2019; Dilrukshi \& Illangarathne, 2019). In contrast, Public Librarians in the Vauniya District of the Northern Province were satisfied with job related factors of responsibility, pay, job security and work itself (Suthakaran, 2019). Findings of prior work have indicated that the job satisfaction of Public Librarians in the North Central Province of Sri Lanka was not at a satisfactory level with regard to different job aspects (Dilrukshi \& Illangarathne, 2019). Yet, there have been no studies conducted to evaluate the levels of job satisfaction of Public Librarians in the Central Province of Sri Lanka. Also, most of the prior studies have employed quantitative methods where as the current study adopted a qualitative research approach to find a detailed solution for the research problem. The current study will contribute in filling this gap in Library Science literature while extending the body of knowledge in the domain of job satisfaction of library employees. Moreover, this study would provide an in depth understanding of Public Librarians' satisfaction with 
their jobs by comprehensively analyzing the job satisfaction in terms of five parameters.

\section{Objectives of the Study}

The overall objective of the study is to examine whether Public Librarians employed in the Kandy District of Sri Lanka are satisfied with their jobs in terms of job role, payment, work supervision, promotion, and co-worker relationships.

The specific objectives of the study are as follows:

1. To find out the factors that determined the Public Librarians' job satisfaction.

2. To detect the problems militating against the Public Librarians' job satisfaction

\section{Review of Literature}

Several studies with regard to the job satisfaction of employees in libraries have been conducted all over the world. Martin (2020) conducted a study to examine the levels of job satisfaction of librarians and library staff and to identify the factors influencing their job satisfaction. Data were gathered via conducting the Job Satisfaction Survey (JSS) among 770 respondents. JSS was a validated, nationally normed instrument which measured the overall job satisfaction and nine sub scales of it. Findings showed that there were no significant differences among the participants by gender, race, library type, position and work. Further, it was revealed that "strength of identification with their current library", "culture and work environment", "colleagues", "leadership", "pay", “diversity and inclusivity", "workload”, "meaningful work", "external recognition of the library's value" and "personal 
appreciation" were salient factors that affected the job satisfaction of librarians and library staff (Martin, 2020, p. 378). In a similar study, Jan and Gul (2020) assessed the job satisfaction among library professionals at government colleges in Pakistan in terms of users, reading habits, conveniences, pay, promotion and professional progress. A questionnaire based survey was employed to collect data. It was revealed that librarians were satisfied with job characteristics such as pay and nature of work where as they were dissatisfied with facets including lack of training and opportunities for professional development as well as no reward system.

In an attempt to detect the relationship between motivation and job satisfaction among staff employed at university Libraries in Nigeria, Idiegbeyan-Ose et al. (2019) found that the job satisfaction of the respondents was low even though their motivation level was high. Kumar (2018) investigated the level of job satisfaction among the 138 university library professionals in four states of India. Study findings demonstrated that the respondents were overall satisfied with their jobs and that there was no significant difference in the job satisfaction with reference to the state, gender, age and experience. In addition, it was revealed that the library professionals were highly satisfied with the 'nature of work' whilst they were dissatisfied with some aspects such as 'operating procedures', 'contingent rewards' and 'promotion schemes'.

In line with the above studies, Igbashalet et al. (2016) explored factors influencing the job satisfaction of librarians in a federal university library. In order to collect necessary data, a survey was performed among a study population of 90 librarians. Findings exhibited that job security as well as satisfactory associations with supervisor, colleagues and customers significantly influenced librarians' job satisfaction. Yet, the 
librarians were not satisfied with salary and fringe benefits, working conditions and available research opportunities. In a similar way, Sambo (2014) focused on the job satisfaction among librarians in Nigeria. The survey strategy was applied to gather data from a sample of 201 librarians. Results indicated that some librarians were highly satisfied with the nature of work in contrast to others who were not satisfied with supervision, benefits, promotion policy, salary structure, and management policy. The author recognized several challenges including low pay, lack of training and technology, staff shortage and poor promotion policy.

In a different study, Hyderand and Batool (2013) conducted a comparative study on job satisfaction among librarians employed in public and private sector universities in Lahore. The study measured eight components of job satisfaction. Findings showed that librarians in the public sector were more in comparison to the librarians in the private sector universities. The authors concluded that there was no significant difference in the level of job satisfaction among librarians serving in both sectors in terms of "physical environment and ICT infrastructure, professional development, organizational culture, social prestige, promotion and nature of work" (Hyder \& Batool, 2013, p. 24).

Khan and Ahmed (2013) opted to determine the job satisfaction of library professionals affiliated to the public sector universities in Pakistan. The authors observed that even though the respondents were slightly satisfied with their nature of work, they were dissatisfied with supervision, benefits and promotions. The authors recommended that measures should be taken to revise the service structure, promotion policies and improve qualifications and training in order to enhance the 
level of job satisfaction among library professionals. In a related study, Farajpahlou and Akhshik (2008) assessed the degree of job satisfaction among librarians in public libraries in South-West Iran with respect to supervision, co-workers, salaries, promotion and general job satisfaction. The results of the study showed that all librarians were satisfied with their job, except for the dissatisfaction towards some aspects such as payments and promotions.

The literature exhibited only a handful of studies conducted in the Sri Lankan context relating to the job satisfaction of library employees. Suthakaran (2019) studied the job satisfaction of public library staff in the Trincomalee District, Sri Lanka by using a self administrated questionnaire, structured interviews and field visits. The author suggested that the authorities should consider hygiene factors to lessen the dissatisfaction of the staff as well as focus on motivational factors to enhance their job satisfaction. In a related study, Dilrukshi and Illangarathne (2019) stressed on the current status and future challenges of the public libraries in the North-Central Province of Sri Lanka and observed that the status of the public libraries was not at a satisfactory level. It was revealed that most of the libraries were administrated by non-professionals and that the library staff was dissatisfied with their promotion scheme. In an attempt to analyze the gender base job satisfaction among public library professionals, Wanasinghe (2019) found both positive and negative signs of job satisfaction among the respondents. In addition, it was concluded that factors relating to job satisfaction of Public Librarians varied according to their gender.

On the other hand, Ranaweera and Li (2018) surveyed university library employees in Sri Lanka and observed that they were fairly 
satisfied with their jobs. Also, co-workers and the nature of work were revealed to be the most significant factors that influenced the job satisfaction. Moreover, Marasinghe and Wijayaratne (2018) examined the gender influence on job satisfaction among university library professionals in Sri Lanka. Findings exhibited that there was a significant difference between male and female professionals in terms of 'supervision'. Yet, the overall job satisfaction of both genders was found to be equal.

Maithili and Navaneethekrishnan (2014) attempted to identify the factors affecting job satisfaction of teacher librarians serving in schools in the Jaffna District. Findings indicated that the majority of teacher librarians were highly satisfied with aspects such as co-workers' behavior, job security and supervision. However, recognition, promotion, salary and working facilities had a negative impact on their job satisfaction. In a similar way, Jeyaraj (2017) examined various causes and constraints which influenced the job satisfaction level of teacher librarians in the Batticaloa District of Sri Lanka. Results showed that teacher librarians had a high level of satisfaction with the variable "job oriented" where as other variables such as "training \& promotion", "management", "work environment", "remuneration" and "colleagues \& subordinates" showed satisfactory levels as "low", "moderate", "moderate", "low", and "moderate" respectively (Jeyaraj, 2017, p. 37). It was found that the major cause which hindered the job satisfaction was the dual functioning of teacher librarians who were expected to teach as well as work as school librarians. The author mentioned that teacher librarians should be motivated and kept happy as well as peaceful to acquire optimum services from them. 
According to the literature it is evident that there is a dearth of studies which examine the job satisfaction of Public Librarians in national and international contexts. In Sri Lanka, a limited number of such studies have been carried out spanning few provinces. Besides, most of those have applied quantitative methods for data collection. Hence, it shows that there is a deficiency of studies with regard to job satisfaction of librarians in the public sector of Sri Lanka, specifically using qualitative approaches. Moreover, there have been no studies which laid focus on assessing the job satisfaction of Public Librarians in the Central Province of Sri Lanka. Thus, the current study contributes towards addressing this gap in the literature while extending the existing body of knowledge with respect to job satisfaction of library professionals. Also, the use of a qualitative approach would help obtain an in-depth understanding of Public Librarians' job satisfaction through the current study.

\section{Methodology}

The main purpose of this qualitative, descriptive study was to explore the levels of satisfaction of Public Librarians with their job in terms of job role, work supervision, promotion, salary and co-worker relationships and to trace out the problems militating against the Public Librarians' job satisfaction. The major variables of this study were selected via an extensive literature review (Table 1). Kandy District had the highest number of public libraries compared with the other districts of the Central Province, Sri Lanka (Table 2). Thus, the Kandy District, with 108 public libraries (as at September 2019), was selected for the study. 


\section{Table 1}

Conceptualization of the Variables

\begin{tabular}{lcc}
\hline \multicolumn{1}{c}{ Variable } & Operational Definition & Source \\
\hline Job role & Is a description of the duties he/she has to & Martin (2020), Jan \& Gul (2020), Esakkimuthu \& \\
& perform in the job? & Vellaichamy (2015), Marasinghe \& \\
& & Wijayaratne (2018), Ranaweera \& Li (2018), \\
& & Maithili \& Navaneethakrishnan (2014), \\
& & Suthakaran (2019)
\end{tabular}




\begin{tabular}{lcc}
\hline \multicolumn{1}{c}{ Variable } & \multicolumn{1}{c}{ Operational Definition } & Source \\
\hline Co-worker & Is a personal, working interaction between the & Jeyaraj (2017) \\
relationships & respondents and other people in the work & Vellaichamy (2015), Ranaweera \& Li (2018), \\
& place. This relationship can be viewed as & Marasinghe, \& Wijayaratne (2018), Jeyaraj \\
cooperation, team spirit, support, trust & (2017). \\
and exchanging information & \\
& Promotion & \\
& a higher job position involving more & Martin (2020), Jan \& Gul (2020), Esakkimuthu \& \\
& work, greater responsibility and higher & Vellaichamy (2015), Marasinghe \& \\
& status. It can include higher level & Wijayaratne (2018), Jeyaraj (2017), Maithili \\
& responsibilities and salary rank. & \& Navaneethakrishnan (2014)
\end{tabular}


Regarding these public libraries 36 employees held the designation of 'Public Librarian' where as 71 others managed the libraries under different job titles. In order to fulfill the objectives of the current study, the authors considered only the Public Librarians

\section{Table 2}

Number of Libraries and Librarians in the Central Province of Sri Lanka

\begin{tabular}{lcc}
\hline \multicolumn{1}{c}{ District } & No. of public libraries & No. of public librarians \\
\hline Kandy & 108 & 37 \\
Matale & 42 & 18 \\
Nuwaraeliya & 43 & 11 \\
\hline Total & 193 & 66 \\
\hline
\end{tabular}

A two-day workshop on 'Attitude Development of Public Librarians' was organized by the Central Library Board of Sri Lanka in September 2019. A total of 35 employees working in public libraries in the Kandy District attended this workshop and out of them only 27 who fell under the category of 'Public Librarian' were selected as the research subjects of the study. The necessary data were collected during the workshop. The researchers explained the objectives of the study and its significance to the participants. The participation for this study was voluntary and it was clarified to all the participants that the collected data will be handled strictly with regard to anonymity and confidentiality issues. The consent from participants was obtained prior to each focus group discussion.

The 27 participants were divided into five groups; with 5 persons in three groups and 6 persons in two groups. This categorization was 
based on their service periods to ensure homogeneity and to capitalize on their shared experiences. Five focus group discussions using a semi structured interview guide were conducted. The duration of each discussion generally lasted between 15 and 20 minutes. Data were collected through note taking. Open ended questions related to the objectives of the study were asked to give them the opportunity to explain their real feelings about job satisfaction. In order to get more information from them, several follow up questions were asked, such as "what do you mean?" or "can you explain more?" or "can you clarify please?".

Interviews were analyzed using the thematic approach and content analysis. Categorization of themes was done based on the five factors and qualitative inferences were made by analyzing the meaning of opinions expressed by the research subjects. Each participant contributed their views and reported their comments to the questions. Thus, there searchers were able to record the respondents' comments and after the discussion participants were asked to write their comments in the provided sheet. After the interview those comments were translated into English. In order to address the credibility and reliability of the study, the data recorded by researchers and the translated data were cross-checked. The secrecy of participants was maintained by not referring to them by their names, rather, numbers were used to identify participants.

\section{Results and Discussion}

The background information of the subjects interviewed is presented in Table 3. According to Table 3, the majority of the participants (96\%) had considerable work experience in the public library 
sector and most of them were female (93\%). Also, a substantial proportion $(37 \%)$ of them belonged to the age category of 41-50.

\section{Table 3}

Distribution of Socio Demographic Characteristics of Respondents $(n=27)$

\begin{tabular}{lcccccccc}
\hline \multirow{2}{*}{$\begin{array}{c}\text { Demographic } \\
\text { Characteristics }\end{array}$} & No. of & $\%$ & \multicolumn{5}{c}{ Focus Group (n) } \\
\cline { 5 - 9 } & Respondents & & 1 & 2 & 3 & 4 & 5 \\
\hline Gender & Male & 2 & 7.4 & 1 & & & 1 & \\
& Female & 25 & 92.6 & 5 & 5 & 5 & 5 & 5 \\
\multirow{2}{*}{ Age } & $20-30$ & 3 & 11.11 & 1 & & & 1 & 1 \\
& $31-40$ & 8 & 29.6 & 2 & 2 & 2 & 1 & 1 \\
& $41-50$ & 10 & 37.0 & 2 & 2 & 2 & 2 & 2 \\
\multirow{4}{*}{ Work } & $51-60$ & 6 & 22.22 & 1 & 1 & 1 & 2 & 1 \\
experience & $1-10$ & 1 & 3.7 & 1 & & & & \\
& $11-20$ & 18 & 66.7 & 3 & 4 & 4 & 3 & 4 \\
& $21-30$ & 8 & 29.6 & 2 & 1 & 1 & 3 & 1 \\
\hline
\end{tabular}

The Public Librarians' job satisfaction was assessed by five key themes that emerged from results of the five focus groups: job role, work supervision, promotion, salary and co-worker's relationship. These were supported by quotes associated with librarians' own ideas. Providing adequately detailed descriptions would allow readers to judge the interpretation. 


\section{Theme 1: Job Role}

All respondents described about their job role and work. Majority of them $(75 \%)$ were satisfied with the work assigned to them. These results were along similar lines with the findings of Kumar (2018) and Sambo (2014) who found that librarians were highly satisfied with "nature of work".

The respondents elaborated that they engaged in the work happily and provided their services to the public by contributing at an optimal level. Following explanations were given by them:

"I feel satisfied when doing work in the library. To do a better service I feel that there should be knowledgeable staff members who were qualified in library science and who had positive attitudes. Then a more effective service can be delivered". (37 Aged, FG: 2)

"I am personally happy with the work assigned as a librarian and I am doing work to the best of my ability". (45 Aged, FG: 2)

Although, the majority of librarians were satisfied with their job role, some explained the challenges they faced when providing services. One experienced Public Librarian stated that:

"I have to do a very big area of work. I am doing my job very satisfactorily; however, responsibility and accountability of the job is high, because every year stock taking is conducted and librarians have to pay when books are lost. Finally, librarians reaching the retirement age get frustrated because they might have to pay a big amount of money". (55 Aged, FG: 1)

Moreover, $25 \%$ of the librarians were unsatisfied with their job role. According to them, in most instances they did not receive the proper reputation and respect from employees of other categories at their work 
place. Few respondents pointed out that in some public libraries only one staff member was serving; thus, he or she had to complete the entire work load from librarian to labourer. As a result, that employee had to face difficulty in obtaining leave when necessary. Further, they stated that the mechanism of recovering money for lost books was inappropriate. Moreover, some of them were not feeling satisfied because the required facilities were not provided to carry out their duties successfully. The respondents' explanations in this regard were as follows:

"Sometimes from the organization side a proper place is not given to the 'librarian' position. In the attendance register and organizational structure librarians' job is marked beneath the management assistant. There is not even a proper desk or chair to the branch librarian. But other office assistants get more comfortable furniture. Organization doesn't care about the requests made by librarian". (40 Aged, FG: 3)

"I have to do all the work from labourer to librarian. It takes around 2 to 3 hours to clean inside and outside of the library. While doing this I have to cater to the users coming to library". (49 Aged, FG: 5)

"Since there are no support staff members, I am doing all the work by myself. Sometimes I missed duties. I can't get leave when I needed. I didn't get a leave for this year up to now. Going to work is unsatisfactory". (42 Aged, FG: 4)

\section{Theme 2: Salary}

Salary is a major component that contributes towards the job satisfaction in any profession. $89 \%$ of the respondents indicated that they were not satisfied with their salary. According to them, their salary was 
low in comparison to other equivalent professions. Furthermore, they had to do much work than the payment they received. Although they had good educational qualifications, they did not receive a satisfactory salary. There should be a mechanism to increase salary according to professional achievements. Some librarians were not kept at the appropriate salary scale. Therefore, they were unsatisfied and de-motivated to work. One of the main factors which caused dissatisfaction with pay in majority of them was that they had to pay from the salary for any book losses in the library. The respondents' opinions about salary were as follows:

"Not enough. Since we have to pay from our salary for lost books". (44 Aged, FG: 5)

"I am not satisfied with my salary. It's not enough at all". (26 Aged, FG: 1)

"The salary for this position is at a very low level and there is no opportunity to discuss this problem". (27Aged, FG: 4)

"Since I'm getting the salary stipulated in 2015, I am not satisfied". (40 Aged, FG: 3)

"According to our educational qualifications, professional level and compared to other professions we are not getting a satisfactory salary". (30 Aged, FG: 5)

Although the majority (89\%) was not satisfied with the salary they received, $11 \%$ of librarians were satisfied with their pay. One respondent mentioned that she was able to manage with the given salary and that she was working happily.

Above findings complement the results of the work done by Farajpahlou and Akhshik (2008). In addition, similar findings were reported by researchers who opted to analyze the job satisfaction of 
library professionals in different sectors such as university library (Igbashal et al. 2016) and school library (Maithili \& Nawaneethakrishnan, 2018). It can be inferred that most of the library professionals, despite the sector of employment, were not satisfied with their salary.

\section{Theme 3: Promotions}

Promotion in the job is one of the motivating factors of job satisfaction. This is significant through the results of the study related to this component. A high percentage $(67 \%)$ of the participants indicated that they were not satisfied with the prevailing promotion scheme. This finding conformed to the results found in studies of Ranaweera and $\mathrm{Li}$ (2018), Wanasinghe (2019), Kumar (2018), Sambo (2014), Farajpahlou and Akhshik (2008) and, Khan and Ahmed (2013).

The reasons for the librarians' dissatisfaction with promotion included: not getting timely promotions, inefficient methodology adopted for promotions and delays in promotions due to tests conducted by the Ministry (e.g., Efficiency bar) were behind schedule. Besides, it was disappointing to note that employees who fulfilled the required qualifications did not get their due promotions. However, 33\% of the Public Librarians were satisfied with the promotion scheme since they got promotions that they strived hard to get and were determined to do the maximum by developing themselves professionally. Under mentioned comments were made by unsatisfied and satisfied respondents:

"After passing the efficiency bar test, no promotions were given for 10 years. Not satisfied". (33 Aged, FG: 3) 
"There are promotions in the government sector but our promotions have problems. Unhappy about that". (35 Aged, FG: 4)

"It's a very pathetic situation. To give my personal story after working as a Library Assistant for 25 years I got Librarian, Grade III. As at now, my service is 25 years. I am close to retirement, no proper methodology adopted to give promotions. Therefore, I am not satisfied". (56 Aged, FG: 3)

"Employees are unfairly treated when promotions are given. Promotions are not given on the right time using the right methodology. Promotions are given when efficiency bar tests were passed. But these tests were not conducted every year and it's unfair". (34 Aged, FG: 5)

"I am satisfied with promotions. But organization doesn't give proper value for this. In that case, I am frustrated". (44 Aged, FG: 3)

"I am happy with my promotions. Regarding my job, I am trying to give a maximum service by improving my professional knowledge". (30 Aged, FG: 5)

\section{Theme 4: Work Supervision}

Supervision plays a salient role in increasing employees' job satisfaction. Work supervision helps employees to improve their skills, knowledge and attitudes towards their job. Employees tend to lose their focus when they lack support from the supervisor and when they are not monitored. The findings exhibited that more than half (59\%) of the participants were not satisfied with their higher level supervision. These findings corroborate with results obtained by Khan and Ahmed (2013) and, Farajpahlou and Akhshik (2008). 
The major reasons for the dissatisfaction of librarians with regard to work supervision were:

- supervision done by people who don't have any knowledge about the library field

- no appreciation for work by the higher authorities and poor recognition in the library sector

- higher management pay less attention to libraries

- higher management is influenced by politicians. It's a hindrance "Support from higher management and financial allocation to the library is getting low. Our requirements are not fulfilled". (26 Aged, FG: 1)

"Higher management is not giving enough attention to the library. They think fulfilling requirements of the library is a problem for them". (31 Aged, FG: 4)

"Since I am working in a local government library I cannot be satisfied with the higher management. They are not giving proper attention to the library". (41 Aged, FG: 2)

"Since higher management has no knowledge about the library work, we face lot of problems when working". (45 Aged, FG: 2)

However, $41 \%$ of librarians were satisfied with work supervision. They said that some knowledgeable supervisors performed their duties properly and that some organizations provided good support and supervision for the development of the library.

"I'm happy about the higher management most of the time. All the resources we require have been provided"'. (49 Aged, FG: 5) 
"Supervision is done properly, since supervising officer is very intelligent. I am satisfied". (42 Aged, FG: 4)

\section{Theme 5: Co-worker Relationships}

Co-worker support has the ability to create a pleasant or unpleasant working environment. According to Hodson (1997) the social relations of the workplace make a vital contribution to employees' job satisfaction, productivity and well-being. In an environment where coworker support is high, employees are able to discuss ideas more openly and honestly which will positively influence the job satisfaction (Fass et al., 2007). All focus groups reported that working with supportive and helpful staff was a major factor that affected job satisfaction. $63 \%$ of librarians were satisfied with their co-worker relationships. Many of them reported that they were satisfied with the cooperation and good relationships among co-workers. Similarly, Maithili and Navaneethekrishnan (2014) observed that teacher librarians were satisfied with co-worker behavior whereas Jeyaraj (2017) pointed out that teacher librarians had a moderate level of satisfaction towards colleagues and subordinates. Moreover, co-worker relationships were identified as a crucial factor effecting the job satisfaction by few researchers in prior studies (Martin, 2020; Ranaweera \& Li, 2018).

Good associations and supportiveness between co-workers is an important sign of that institute being a pleasant working place. Two librarians explained their positive comments towards co-workers as follows:

"The staff that I have at the moment is giving very good help and services". (53 Aged, FG: 5) 
"The work is carried out very supportively, since there are two employees in the library, we carry out the work very happily". (56 Aged, FG: 2)

Even though, the majority of Public Librarians expressed satisfaction, $26 \%$ of them were unsatisfied with co-worker relationships. $11 \%$ of librarians mentioned that they were working without co-workers. During the focus group discussions some reasons for their dissatisfaction were revealed. Respondents outlined those co-workers were not supportive during work. Also, employees had to be constantly reminded about their work and since some were working in the same division for a long period of time, it was difficult to control them and to get support to complete routine work. Further, employees who got appointments through political influences were not carrying out their duties properly as well as they were not providing support to the management and colleagues. Respondents articulated their dissatisfaction as follows:

"Since support staff is working in the same place for a very long time and they are not transferred it is difficult to work with them and control them". (49 Aged, FG: 5)

"Have to face a lot of inconveniences when working with people who have different attitudes". (39 Aged, FG: 5)

\section{Conclusion}

Job satisfaction is an important attribute for every organization since satisfied employees are highly productive and would make a significant contribution to the development of the organization. Many factors like work environment, job role, salary and promotion, collectively contribute to the job satisfaction. It is highly important that 
the management adopt necessary measures to form job satisfaction among the employees to accomplish organizational goals successfully. An organization should conduct studies such as surveys to capture the feelings of employees towards job satisfaction periodically and implement strategies for continuous improvement of the level of job satisfaction among them (Esakkimuthu \& Vellaichamy, 2015).

Findings of the present study indicated that the majority of Public Librarians were satisfied with two parameters out of five: job role (75\%) and co-workers' relationships $(63 \%)$. However, a higher proportion of them were not satisfied with salary $(89 \%)$, and promotion scheme $(67 \%)$ where as more than half of the respondents (59\%) showed dissatisfaction in work supervision. Based on the findings, it is observed that the three factors; salary, promotion and work supervision negatively affected the Public Librarians' job satisfaction. In addition, it is observed that the opinions of Public Librarians do not significantly differ to those of library professionals in other sectors. Prior research indicated that majority of librarians had negative views with regard to the pay, promotions and work supervision despite their employment sector. Moreover, based on the study findings following problems were identified with regard to their dissatisfaction.

1. Recovering strategy for lost books

2. Poor recognition \& reputation on the librarians' post

3. Educated librarians were not placed in the appropriate salary scale

4. Not getting timely promotions and the methodology has many flaws when implemented

5. Supervision done by people whoare not qualified in the library discipline 


\section{Unnecessary political influences}

It can be concluded that by taking effective and feasible measures to address the above problems the level of job satisfaction of Sri Lankan Public Librarians could be improved. In the light of the findings, several pragmatic recommendations have been exposed.

The ministry of the local government of Sri Lanka should pay attention on the difficulties and practical problems librarians face in the field. It is recommended that a common policy which is unbiased towards librarians be developed for recovering book losses. Also, the recognition of the librarians should be improved via placing them in the correct level of the organizational hierarchy and it is important to give due respect to them. In addition, higher authorities should consider improving the salary levels and streamline the promotion strategy. It is suggested that more incentives and attractive salary packages be introduced to inspire the librarians so that it will lead to high levels of job satisfaction among them. Further, it is important to implement performance appraisal schemes to appreciate the valuable efforts and contributions of productive employees and help boost their motivation to engage in work more effectively.

It is essential that the interviews and exams associated with promotions be conducted on schedule in order to minimize unnecessary delays. Furthermore, respective authorities should take necessary measures to assign people who possess sound knowledge on library science for work supervision in public libraries. "Regular feedback, better guidance and encouragement by the supervisors" (Marasinghe \& Wijayaratne, 2018, p. 17) are crucial in boosting the job performance. This will help the librarians to overcome their frustration and to enhance 
their capacity and existing knowledge. Nevertheless, the management should open avenues for the professional development of the Public Librarians through offering them exposure to seminars, workshops and other training programs which would help enhance the efficiency and value of their services. In addition, it is advisable to improve the work conditions of public libraries including the development of infrastructure facilities. It is important to maintain a pleasant working environment for the Public Librarians so that they could work happily and peacefully which will in turn enhance their work productivity. Further, it will help retain more satisfied and committed librarians in the library services who would deliver an effective service to the user base.

Public libraries are prominent information hubs that render knowledge resources and services to the entire community. Thus, the role of Public Librarian becomes highly significant in the society and their satisfaction and commitment will have an impact on the effectiveness and efficiency of the offered services. The findings of the study provide important suggestions for improving the quality of work, librarians' satisfaction and overall development of public library services.

The setting for the present study was limited to one district (Kandy) in the Central Province of Sri Lanka and also only the employees serving under the designation of 'Public Librarians' were used as the research subjects. This same study can be repeated using all Public Librarians in Sri Lanka and similar studies applying the qualitative approach can be conducted using different professionals (e.g., library assistants), in diverse library contexts such as university libraries, private libraries, school libraries etc. This study can be extended by incorporating other job-related facets such as work environment, job 
security, reward systems, infrastructure, personal growth and policies in order to examine the librarians' job satisfaction. Moreover, the current study could be improved by gathering quantitative data from the respondents using a survey in order to complement the qualitative data which would render further insight into the job satisfaction of Sri Lankan Public Librarians. 


\section{References}

Dilrukshi, T., \& Illangarathne, S. K. (2019). Current status and future challenges of the public libraries in Sri Lanka for the pattern change: A case study. In M. K. Weerasinghe \& W. A. Weerasooriya (Eds.), Proceedings of $3^{\text {rd }}$ International Conference on Library and Information Management (pp. 100-103). University of Kelaniya. https://www.academia.edu/42876856 /3_rd_International_Conference_on_Library_and_Information_M anagement_ICLIM_2019_PROCEEDINGS?auto=download

Esakkimuthu, C., \& Vellaichamy, A. (2015). Job satisfaction among the library professionals in engineering institutions: An empirical study. International Journal of Digital Library Services, 5(1), 2237.

Farajpahlou, H., \& Akhshik, S. S. (2008). A survey of job satisfaction among librarians in public libraries in south west Iran. Journal of Educational Sciences, 14(4), 159-180.

Fass, R. D., Bishop, J. W., \& Glissmeyer, M. (2006). Perceived coworker support and task interdependence in law enforcement. Decision Sciences Institute. http://www.swdsi.org/swdsi07/ 2007_proceedings/papers/535.pdf

Hodson, R. (1997). Group relations at work: Solidarity, conflict, and relations with management. Work and Occupations, 24(4), 426452.

Hulin, C. L., \& Judge, T. A. (2003). Job attitudes. In: W. C. Borman, D. R. Ligen \& R. J. Klimoski (Eds.). Handbook of psychology: Industrial and organizational psychology. John Wiley \& Sons. 
https://www.researchgate.net/publication/267796178_Handbook_ of_Industrial_and_Organizational_Psychology

Hyder, M., \& Batool, S. H. (2013). Job satisfaction among public and private university/degree awarding institution librarians of Lahore: A comparative study. Pakistan Journal of Library \& Information Science, 14(14), 16-25.

IFLA/UNESCO. (2019, January 19). IFLA/ UNESCO public library manifesto 1994. http://www.ifla.org/publications/iflaunescopublic-library-manifesto-1994

Idiegbeyan-Ose, J., Opeke, R., Aregbesola, A., Owolabi, S., \& Eyiolorunshe, T. A. (2019). Relationship between motivation and job satisfaction of staff in private university libraries, Nigeria. Academy of Strategic Management Journal, 18(1), 1-13.

Igbashal, A. A., Beetseh, K., \& Kumba, L. (2016). Factors affecting librarians job satisfaction in federal university of Agriculture Makurdi Library. International Journal of Academic Library and Information Science, 4(9), 264-270.

Iurun, D. P. (2014). Factors affecting librarian job satisfaction in Benue State University Makurdi [Unpublished project work]. Department of Educational Foundation, Benue State University. http://bsuir.bsum.edu.ng/

Jan, S. U., \& Gul, S. (2020). Job satisfaction among library professionals at Government Colleges of Commerce and Management Sciences of Khyber Pakhtunkhwa. Library Philosophy and Practice. https://digitalcommons.unl.edu/libphilprac/3966/ 
Jeyaraj, W. J. (2017). Job satisfaction level of teacher librarians of national schools in the Batticaloa District of Sri Lanka. Journal of Research in Humanities and Social Science, 5(6), 34-41.

Kaliya, P., \& Baskaran, S. (2010). Information seeking behaviour of rural folk in Tamil Nadu: A case study of Peramakudi branch library. Kelpro Bulletin, 4(2), 49-59.

Khan, A., \& Ahmed, S. (2013). Job satisfaction among librarians in the universities of Khyber Pakhtunkhwa, Pakistan: A survey. Library Philosophy and Practice. http://digitalcommons.unl.edu/ libphilprac/906

Kumara, B. (2018). A study of job satisfaction among library professionals. International Journal of Information Movement, 2(11), 62-68.

Maithili, V. \& Navaneethakrishnan, S. (2014). Job satisfaction of teacher-librarians: A case study of the Jaffna district, Sri Lanka. Chinese Librarianship: An International Electronic Journal, 38, 77-83.

Marasinghe, M. P. L. R., \& Wijayaratne, A. (2018). The impact of gender differences on job satisfaction of University Library Professionals. Journal of the University Librarians Association of Sri Lanka, 21(2), 1-20.

Martin, J. (2020). Job satisfaction of professional librarians and library staff. Journal of Library Administration, 60(4), 365-382.

Olusegun, S. O. (2013). Influence of job satisfaction on turnover intentions of library personnel in selected universities in South West Nigeria. Library Philosophy and Practice, 914. https://digitalcommons.unl.edu/libphilprac/914 
Ranaweera, R. A. A. S., \& Li, S. (2018). Job satisfaction of staff in university libraries in Sri Lanka. International Journal of Organizational Innovation, 11(1), 1-9.

Sambo, A. S. (2014). A survey of job satisfaction among librarians in Nigerian libraries. Information Impact, 5(1), 41-54.

Suthakaran, V. (2019). Job satisfaction among public library staff in Trincomalee District. UWU e-Repository, Uva Wellassa University. http://www.erepo.lib.uwu.ac.lk/bitstream/handle/ 123456789/589/389.pdf? sequence=1\&isAllowed $=\mathrm{y}$

Wanasinghe, W. M. P. G. K. T. (2019). Job Satisfaction among public library professionals: A gender base comparison. In M.K. Weerasinghe \& W.A. Weerasooriya (Eds.), Proceedings of $3^{\text {rd }}$ International Conference on Library and Information Management (pp.309-313). University of Kelaniya. https://www.academia.edu/42876856/3_rd_International_Confere nce_on_Library_and_Information_Management_ICLIM_2019_P ROCEEDINGS?auto=download 